\title{
Enterooxyntin Release from Isolated Perfused Canine Jejunum ${ }^{1}$
}

\author{
W. A. Walker, M.D., W. E. Strodel, M.D., F. E. Eckhauser, M.D., \\ A. HeldSINGER, B.S., AND A. I. VINIK, M.D. \\ Departments of Surgery and Internal Medicine, University of Michigan, Ann Arbor, Michigan 48109
}

Presented at the Annual Meeting of the Association for Academic Surgery,

San Diego, California, November 7-10, 1982

\begin{abstract}
A humoral factor may mediate the intestinal phase of gastric acid secretion. An ex vivo perfused segment of canine jejunum maintained by an oxygenated asanguinous physiologic perfusate was used to test for release of an enterooxyntin ( $\mathrm{EO}$ ) in response to balloon distention at $30 \mathrm{~mm} \mathrm{Hg}$ for $15 \mathrm{~min}$. Gastric acid secretion in guinea pig fundic mucosa was determined indirectly by a quantitative cytochemical bioassay (CBA) of oxyntic cell hydroxyl ion production (HIP). An increase in the optical density (OD) caused by the cytochemical stain in the oxyntic cells reflects HIP, an index of acid secretion. Basal OD for segments with distention was $16.6 \pm 0.53$ and for those without $15.5 \pm 0.68$ (NS). Results are expressed as mean change of OD from basal (mean $\triangle O D \pm S E M$ ).
\end{abstract}

Time (min)

\begin{tabular}{lcccc}
\cline { 2 - 4 } & 10 & 30 & 60 & 120 \\
\hline Mean $\Delta O D$, distention & $4.9 \pm 1.6^{*}$ & $5.9 \pm 1.1^{*}$ & $7.2 \pm 1.2^{*}$ & $5.2 \pm 0.9^{*}$ \\
Mean $\Delta O D$, no distention & $-0.6 \pm 1.0$ & $-0.1 \pm 0.8$ & $0.58 \pm 1.0$ & $0.7 \pm 1.2$
\end{tabular}

* Significant stimulation of HIP $(P<0.02)$ by EO.

EO caused greater stimulation of HIP than gastrin or histamine. EO was heat stable. Trichloroacetic acid treatment decreased EO activity as did pronase digestion suggesting that EO is composed of one or more peptides. Conclusion: EO, an acid secretagogue, is a humoral agent probably composed of one or more peptides and is released by small bowel distention. Mechanical distention of the small bowel may be an important mechanism for the perpetuation of gastric acid secretion. The ex vivo perfused jejunal segment in conjunction with the CBA are ideal tools with which to study mechanisms of relcasc of $\mathrm{EO}$ and the mechanism of action of $\mathrm{EO}$ on the oxyntic cell.

\section{INTRODUCTION}

The presence of an intestinal phase of gastric secretion has been recognized since the work of Le Conte [17] and Pavlov [26] in the early twentieth century. In 1953, Sircus demonstrated that simple mechanical distention of the jejunum in the dog resulted in increased acid secretion from a denervated gastric pouch and suggested that a humoral agent caused the intestinal phase of gastric acid secretion [29]. Perfusions of Thiry-Vella loops, small intestine and gastrojejunostomies with nutrient solutions in dogs with Heidenhain

\footnotetext{
I This work was supported by a grant from the National Institute of Health (USPHS - Am - 27077).
}

pouches, support the concept that a humoral mediator of the intestinal phase response exists $[1,2,7,14,16,31]$. In both dogs and man, a humoral agent has been suggested as the agent causing the increase in gastric acid secretion following portacaval shunting $[12$, $22,24]$. Grossman proposed the name enterooxyntin (EO) for the putative humoral substance released by the gut which stimulates the gastric oxyntic cell to produce acid [9].

We have used distention of an ex vivo isolated perfused segment of canine jejunum to release an acid secretagogue which satisfies the definition of EO. Using a sensitive quantitative cytochemical bioassay (CBA) of oxyntic cell hydroxyl ion production (HIP) as an in- 
dex of acid secretion [13], we measured the ability of EO to stimulate the oxyntic cell. In the CBA, EO was at least as efficacious as histamine or gastrin. Preliminary characterization of EO suggests that it is composed of one or more relatively heat stable peptides.

\section{METHODS}

Jejunal perfusion. Mongrel dogs of both sexes weighing between 15 and $25 \mathrm{~kg}$ were anesthetized with pentobarbitol sodium (Nembutol), intubated, and ventilated. Through a midline incision, a $30 \mathrm{~cm}$ segment of jejunum beginning $5 \mathrm{~cm}$ distal to the ligament of Treitz was isolated. The jejunum was divided and the lumen was perfused with normal saline at a rate of $1.67 \mathrm{ml} / \mathrm{min}$. The cephalad mesenteric artery and vein were then cannulated and pulsatile perfusion begun at a flow rate of $35 \pm 5 \mathrm{ml} / \mathrm{min}$. Any remaining attachments of the segment of jejunum were severed and the specimen placed on the perfusion apparatus. The jejunal segment was maintained on a sheet of polyethylene suspended in a water bath at $37^{\circ} \mathrm{C}$ in a closed chamber.

The perfusate consisted of a modified Krebs-Henselit solution containing: sodium $145 \mathrm{meq} /$ liter, glucose $7 \mathrm{mmole} / \mathrm{liter}$, bovine serum albumin $0.6 \mathrm{mmole} / \mathrm{liter}$, phosphorus $3.8 \mathrm{meq} / \mathrm{liter}$, and dextran (avg. M.W. 70,000) $8.5 \mathrm{mmole} / \mathrm{liter}$.

The perfusate was heated and oxygenated with a humidified $95 \% \quad \mathrm{O}_{2}-5 \% \mathrm{CO}_{2}$ mixture using a modified rotating disc oxygenator (Sarnes Co., Inc.) suspended in the water bath. Organ perfusion was provided with a pulsatile pump (Harvard Apparatus, Model 1405). A single-pass perfusion technique was used so that fresh oxygenated perfusate entered via the arterial cannula, exited the segment via the venous cannula, and was retained for assay. This system is similar to that described by Eckhauser et al. for ex vivo perfusion of the pancreas and duodenum except that the perfusate is not recirculated [6].

Three milliliters of venous effluent were taken at $0,10,30,60$ and $120 \mathrm{~min}$ after a 10 min baseline period, placed in a polyethelene tube, and immediately frozen in a solid $\mathrm{CO}_{2}-$ ethanol bath at $-70^{\circ} \mathrm{C}$.

Perfusions without distension (control). After removal from the dog, the bowel was perfused for $130 \mathrm{~min}$. Arterial flow was maintained at $35 \pm 5 \mathrm{ml} / \mathrm{min}$ and the lumen was perfused at $1.67 \mathrm{ml} / \mathrm{min}$ with normal saline. No luminal distention was applied. Samples of effluent for testing in the CBA were taken 10 min after beginning the perfusion to determine basal activity, and labeled as time 0 min. Additional samples were taken at 10,30, 60 , and $120 \mathrm{~min}$. Samples of jejunal tissue for histologic examination were obtained before and after the perfusion. Minimal differences were observed between these sections consisting of mild edema and loss of the tips of some villi, suggesting that the bowel remained viable.

Perfusions with distention (experimental). After removal from the dog, the bowel was perfused for $130 \mathrm{~min}$. Arterial flow was maintained at $35 \pm 5 \mathrm{ml} / \mathrm{min}$. Samples of effluent for testing in the CBA were taken $10 \mathrm{~min}$ after beginning the perfusion to determine basal activity and labeled as time 0 . Immediately after obtaining this sample, the lumen was intubated with a latex rubber balloon which was inflated to $30 \mathrm{~mm} \mathrm{Hg}$. After $15 \mathrm{~min}$ of bowel distention, the tube was removed and perfusion with normal saline at $1.67 \mathrm{ml} / \mathrm{min}$ was resumed. Additional samples of perfusate were obtained at $10,30,60$, and 120 min after time 0 for testing in the CBA. Sections of jejunum before and after distention and perfusion were examined histologically and showed minimal changes between the sections consisting of tissue edema and loss of some tips of villi.

Quantitative cytochemistry of oxyntic cell function. After an overnight fast, female guinea pigs weighing 450 to $500 \mathrm{~g}$ were sacrificed by asphyxiation in a nitrogen atmosphere and their stomachs were rapidly removed. A 3-4 $\mathrm{cm}$ strip of gastric fundus was excised from a standard area just below the esophagogastric junction. The tissue was rinsed in $0.025 \mathrm{M}$ HEPES (Sigma) buffer, (pH adjusted to 7.0 
with $10 \mathrm{M} \mathrm{KOH}$ solution) and divided into 3-5 $\mathrm{mm}$ pieces. These were snap-frozen in a beaker immersed in an $n$-hexane, solid $\mathrm{CO}_{2}$, absolute alcohol freezing mixture. The frozen portions of tissue were used within $72 \mathrm{hr}$ of freezing.

Sections $(18 \mu \mathrm{m})$ were cut from the mounted tissue in a $-20^{\circ} \mathrm{C}$ cryostat. Sections were mounted on glass slides using a template to reliably position the sections in a predetermined area and stored for no longer than $6 \mathrm{hr}$ in the cryostat chamber before use in the assay.

The slides were placed flat, section upwards. in a slide tray and allowed to equilibrate to room temperature for $10 \mathrm{~min}$. The test solutions were diluted to desired concentrations in 0.025 $M$ HEPES buffer at $\mathrm{pH} 7.0$. One hundred microliters of each solution was delivered by a dispensing apparatus designed to deliver precise volumes of test solution directly and simultaneously to 24 sections and allowed to react with the sections at room temperature $\left(20^{\circ} \mathrm{C}\right)$ for $90 \mathrm{sec}$. The reaction was terminated by the addition of the staining reagents. Within each experiment each test solution was reacted with tissue sections in triplicate.

Production of hydroxyl ions (HIP) was quantified by a modification of Hansson's mcthod [10] using $10.5 \mathrm{mM} \mathrm{CoSO}_{4}, 53 \mathrm{mM}$ $\mathrm{H}_{2} \mathrm{SO}_{4}, 157 \mathrm{mM} \mathrm{NaHCO}_{3}$, and $1.17 \mathrm{mM}$ $\mathrm{KH}_{2} \mathrm{PO}_{4}$ in $0.1 M$ HEPES buffer at $\mathrm{pH} 7.4$ with $0.001 \%$ gum tragacanth. This solution was applied so as to just cover the sections. The staining reaction was allowed to proceed with gentle agitation for $2 \mathrm{~min}$ at $20^{\circ} \mathrm{C}$ and then the sections were washed twice with cold water after which they were exposed to a saturated solution of $\mathrm{H}_{2} \mathrm{~S}$ in water for $90 \mathrm{sec}$, again washed in water and mounted in Farrants Medium (G. D. Searle Diagnostics, High Wycombe, Bucks, England). The staining procedure led to the formation of visible brown precipitates of $\operatorname{CoS}$ within the sections: the most deeply stained cells were the oxyntic cells. The amount of precipitate formed is a reflection of the number of hydroxyl ions trapped [10] and was quantitated by means of a M85 scanning and integrating microdensitometer [5]. This staining is based on the reaction between $\mathrm{Co}^{3+}$ and $\mathrm{OH}^{-}$ions produced during stimulation of the oxyntic cell. Whether these hydroxyl ions are produced by carbonic anhydrase (CA) or are produced by the proton pump is unknown. It has been suggested that $\mathrm{CA}$ catalyzes directly the reaction between the hydroxyl ion produced by the proton pump and $\mathrm{CO}_{2}$ resulting in the formation of a bicarbonate ion [27]. This process requires fewer reactions than that proposed by Maren [20] and fits with observed events just as well. I hus, we believe the staining actually quantifies hydroxyl ions produced by the proton pump. This would provide a direct measurement of hydrogen ion secretion by the oxyntic cell and should parallel HIP mole for mole.

The cells selected for each reading were those which completely filled a mask which, when used with the $25 \times$ objective lens has a field diameter of $20 \mu \mathrm{m}$. Fifteen to twenty oxyntic cells in each of the randomized coded sections were read at $550 \mathrm{~nm}$. The same number of measurements was made from the muscularis mucosa in each section. Readings from the muscularis reflect nonspecific absorption of $\mathrm{CoS}$ to tissue and were therefore, subtracted from those of the oxyntic cells. To correct for possible instrument variation, the densitometer was calibrated by taking readings of a standard filter of known optical density before and after taking readings from each section. Values for the optical density of the CoS precipitate in each section were read as integrated extinction and were expressed as a percent using the following equation: (mean extinction of oxyntic cells) - (mean extinction of muscularis) $\times 100 / D$, where $D$ is the reading of a standard filter with an optical density of 1 . The optical density thus calculated allowed comparisons between sections.

Characterization of $E O$. Preliminary characterization of the nature of EO was carried out on samples of perfusate shown to cause oxyntic cell HIP. HIP was measured before and after boiling for $10 \mathrm{~min}$ to test heat stability. To determine if EO was a peptide, a 


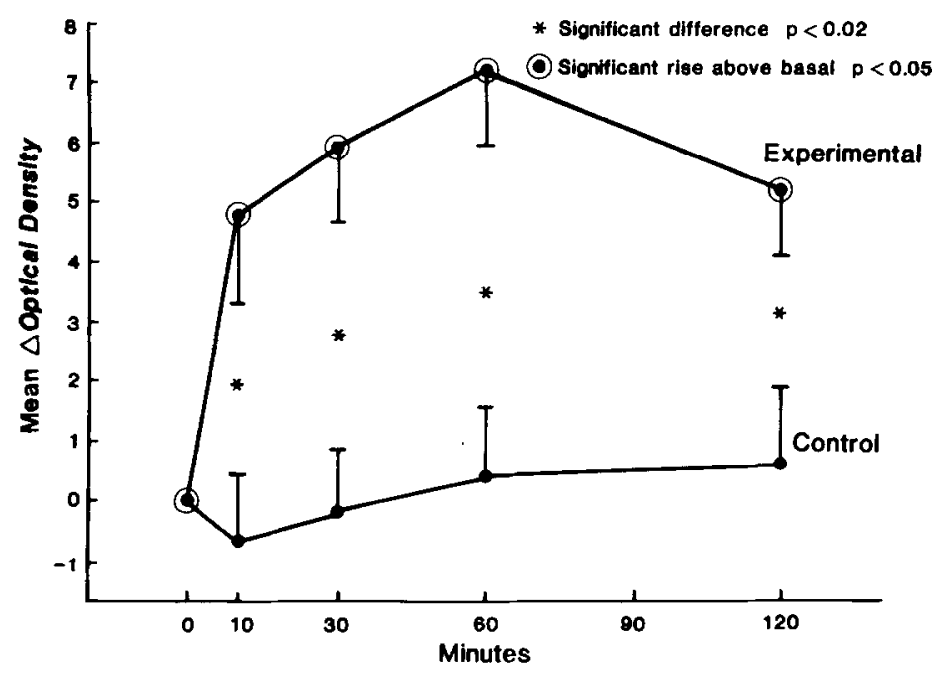

FIG. 1. Comparison of hydroxyl ion production (HIP) with and without distention of the segment. Mean $\triangle$ optical density reflects change of hydroxyl ion production from basal. $O=$ Significant stimulation of HIP $(P<0.02)$ above basal. * - Significant difference between control and experimental.

sample containing EO was treated with $20 \%$ cold trichloracetic acid and the residual HIP measured in the supernatant. The importance of peptide bonds was determined by measuring HIP before and after a sample containing EO was treated with Pronase to destroy peptide bonds [11].

Statistics. The significance of the difference between the mean optical density (OD) of the oxyntic cells during the basal periods for the control and experimental groups was tested using Student's $t$ test. Following the basal period, the change in OD between the basal value and subsequent values at $10,30,60$, and 120 min was determined for the experimental and control groups and the significance of the difference between groups in the mean change in $\mathrm{OD}$ (mean $\triangle O D$ ) was determined for each time point using Student's $t$ test. A $P$ value less than 0.05 was accepted as significant.

\section{RESULTS}

During the $10 \mathrm{~min}$ basal period, treatment of oxyntic cell sections with venous effluent from the control perfusions $(n=3)$ rcsulted in a mean OD of $15.5 \pm 0.68$, while treatment with effluent from the experimental perfusions $(n=3)$ resulted in a mean OD of 16.6 \pm 0.53 . This difference was not statistically significant.

The mean OD in the CBA did not change from basal in the control group. In the experimental group, there was a significant rise in OD $(P<0.02)$ caused by the venous effluent (Fig. 1).

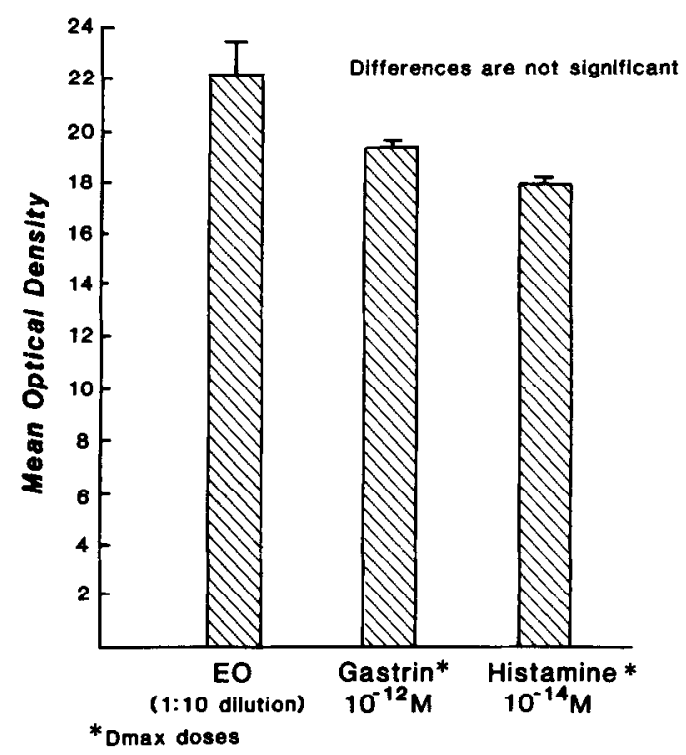

FIG. 2. Comparison of EO, gastrin and histamine on oxyntic cell HIP. Mean optical density reflects HIP. 


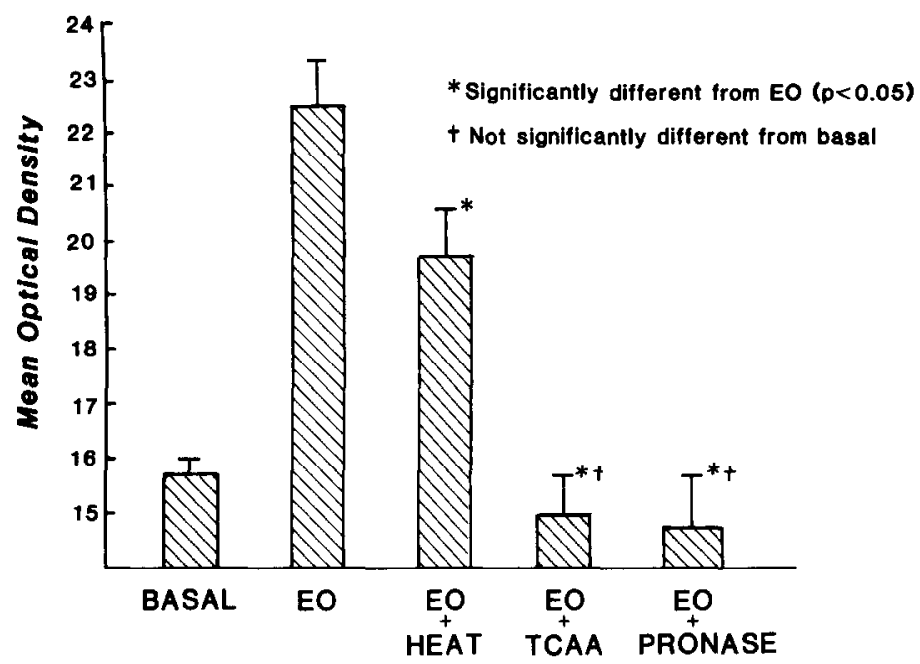

FIG. 3. The effects of heat, trichloroacetic acid (TCAA) and pronase on HIP caused by EO. * = Significant difference compared to $\mathrm{EO}$ alone $(P<0.05)$.

Comparison with gastrin and histamine. The peak value obtained from venous effluent of distended jejunum was $22.32 \pm 1.29$ seen at $60 \mathrm{~min}$. This compares to a peak of 19.44 \pm 0.22 for gastrin $\left(10^{-12} M\right)$ and $17.97 \pm 0.24$ for histamine $\left(10^{-14} M\right)$ (Fig. 2).

Physical characteristics of EO. After boiling venous effluent from distended segments, HIP in oxyntic cells was $59 \%$ of the value before boiling.

Treatment with $20 \%$ trichloroacetic acid and pronase completely prevented stimulation of HIP in the oxyntic cell by the perfusate samples. The results are shown in Fig. 3.

\section{DISCUSSION}

The cytochemical bioassay (CBA) used to measure hydroxyl ion production (HIP) by the oxyntic cell has been shown to reflect activation of guinea pig oxyntic cells by gastrin, histamine, and carbamylcholine, the three known acid secretagogues [13, 19, 28, 30]. Although this method does not directly measure hydrogen ion secretion, all current proposals to explain hydrogen ion secretion by the oxyntic cell require generation of intracellular hydroxyl ions [27]. Thus, measurement of hydroxyl ion production may well reflect acid secretion.
A number of studies indicated that the jejunum is the site of origin of an acid secretagogue tentatively termed enterooxyntin [1, $2,4,8,9,16,25,31]$. However, it has not been clearly established that a hormone rather than the infused nutrient such as amino acids was the functional secretagogue [21]. For this reason, we chose to examine the effects of simple distention of the canine jejunum on the release of EO. The use of an ex vivo preparation offers several benefits. Removal of the jejunum severs all neural components and vascular components extrinsic to the segment of jejunum. Vascular and luminal flow are controlled and may be varied. Use of an artificial perfusate avoids contamination by other agents contained in plasma. $\wedge$ once through perfusion system avoids accumulation of waste products or active agents and allows an accurate evaluation of the time course of release. In addition, no major site of metabolic degradation such as the liver is present.

Earlier studies in our lab showed that the perfused bowel segment remained viable for about 2 hr. Histologic changes in the jejunum perfused for $2.5 \mathrm{hr}$ or less showed minimal changes consisting of edema and loss of a few villi tips. Prolonged perfusion ( $>3 \mathrm{hr}$ ) or perfusion at reduced flow rates $(<30 \mathrm{ml} / \mathrm{min})$ 
resulted in gross histologic evidence of cell death with loss of mucosa and necrosis of the muscularis.

Using this system, a definite and sustained release of a substance from the distended jejunum which stimulates HIP in guinea pig oxyntic cells was found. Since HIP was the same under basal conditions and there was no change during perfusion without distention, the release of EO is presumably due to distention of the jejunum and not the perfusion process itself. Because this substance is released into the venous effluent and stimulates the oxyntic cell, we have used the term enterooxyntin (EO) as first proposed by Grossman [9] to describe an agent released from the bowel causing stimulation of the oxyntic cell.

The mechanism of release of EO is unknown. Possible explanations include local neural pathways involving the enteric nervous system or direct action of stimuli on cells containing EO. Our model does not answer this question and either possibility may occur. Direct trauma to EO-containing cells by the perfusion process and balloon distention may cause release. Since no release was seen in control perfusions, the stimulus to secretion is likely to have been balloon distention.

After release of EO was established, a preliminary characterization was performed. EO was identified as a likely acid secretagogue. Comparison with histamine and gastrin indicated that EO was at least as efficacious a stimulus of HIP as gastrin and histamine. This may reflect a single more potent agent, the additive effects of several different agents released into the perfusate, or potentiation of local histamine within the gastric tissue. Treatment with trichloroacetic acid destroyed HIP stimulation indicating that the active substance was protein in nature. Pronase digestion destroyed the ability of EO to stimulate HIP indicating that peptide bonds are important in the action of EO. EO was relativcly heat stable. These findings support the concept that the circulating agent or agents which comprise EO are made up of one or more peptides.
Since EO is believed to be at least partially responsible for the intestinal phase of acid secretion, it may be important in the development of peptic ulcer disease. Konturek et al. studied the effects of intestinal meals in patients with and without peptic ulcer disease. A distinct intestinal phase of gastric secretion was observed with a higher level of acid production present in patients with duodenal ulcer [15]. Bugat $e t$ al. have shown that a gastric secretagogue that is not gastrin exists in patients with peptic ulcer disease [3]. EO may contribute to this effect. Experiments by Orloff $e t a l$. have suggested that the increase in gastric acid secretion after portacaval shunting is mediated by a humoral agent which escapes hepatic degradation and is released from the jejunum $[23,25]$. Our findings do not exclude the possibility that EO may be extracted by the liver and the stimulation of HIP we see may be due to an increased level of EO which might not be seen after circulation through the liver. Further study of the mechanisms of release of EO and its action on the oxyntic cell may provide a better understanding of the role of EO in acid secretion and peptic ulcer disease.

In summary, our study demonstrates the release into the venous system of an agent from the perfused, distended jejunum which was capable of stimulating the oxyntic cell, thus fulfilling the definition of enterooxyntin. Preliminary characterization suggests that EO is composed of one or more peptides. The $e x$ vivo perfused jejunal segment and CBA are useful tools in the study of the release and action of EO.

\section{REFERENCES}

1. Alday, E. A., and Goldsmith, H. S. Gastric hypersecretion after antacid infusion into the small intestine. Surg. Gynecol. Obstet. 139: 333, 1975.

2. Alday, E. A., and Goldsmith, H. S. Small intestine control of gastric secretion. Surg. Gynecol. Obstet. 136: 185, 1975.

3. Bugat, R., Walsh, J. H., Ippoliti, A., Elashoff, J.. and Grossman, M. I. Detection of a circulating gastric secretagogue in plasma extracts from normogastrinemic patients with acid hypersecretion. C.U.R.E. Preprint 144, July 15, 1976. 
4. Clain, J. E., Malagelada, J. R., Go, V. T. W., and Summerskill, W. H. J. Participation of the jejunum and ileum in postprandial gastric secretion in man. Gastroenterology 73: 211, 1977.

5. Deeley, E. M. An integrating microdensitometer for biological cells. J. Sci. Instr. 32: 263, 1955.

6. Eckhauser, F. E., Knol, J. A., Porter-Fink, V., Lockery, D., Edgcomb, L., Strodel, W. E., Webb, D., and Simmons, J. Ex-vivo normothermic hemoperfusion of the canine pancreas: Applications and limitations of a modified experimental preparation. J. Surg. Res. 31: 22, 1981.

7. Grabner, P., Donahue, P. E., Torma-Grabner, E., Kalabraser, N. G., Bombeck, C. T., and Nyhus, T. M. Non-gastrin intestinal phase secretion: Experimental confirmation in the dog. Scand. J. Gastroenterol. 15: 165, 1980.

8. Grabner, P., Semb, T. S., Schrumpf, E., and Myren, J. The intestinal phase of gastric secretion: Response to liver extract infusion into the proximal jejunum of healthy human subjects. Scand. J. Gastroenterol. 11: $415,1976$.

9. Grossman, M. I, et al. Candidate hormones of the gut. Gastroenterology 67: 730, 1974.

10. Hansson, H. P. J. Histochemical demonstration of carbonic anhydrase. Histochemie 11: 112, 1967.

11. Harold, A. In Victor Rodwell (Ed.), Amino Acids and Proteins. Los Altos, California: Lange Medical Pub., 1969. Vol. 12, p. 37.

12. Kester, R. C. The intestinal phase of gastric secretion. Ann. R. Coll. Surg. Engl. 56: 231, 1975.

13. Klaff, L. J., Vinik, A. I,, and Heldsinger, A. In R. P. Miller (Ed.), Neuropeptides: Biochemical and Physiological Studies. New York: Churchill, I ivingstone 1981.

14. Konturek, S. J., Kaers, H., and Kwiecien, N. Stimuli for intestinal phase of gastric secretion in dogs. $\mathrm{Am}$. J. Physiol. 234 (1)E: 64, 1975.

15. Konturek, S, J., Kwiecien, W., Obtulowicz, E., and Oleksy, J. Intestinal phase of gastric secretion in patients with duodenal ulcer. Gut 19: 321, 1978.

16. Konturek, S. J., and Grossman, M. 1. Effect of perfusion of intestinal loops with acid, fat, or dextrose on gastric secretion. Gastroenterology 49: 481, 1965.

17. LeConte, P. LaCellule, 17: 285, 1900.

18. Loveridge, N. A quantitative cytochemistry method for measuring carbonic anhydrase. Histochem. $J .10$ : $361,1978$.
19. Loveridge, N., Bloom, S. R., Welbourne, R. B., and Chayen, J. Quantitative cytochemical estimation of the affect of pentagastrin $(0.005-5 \mathrm{pg} / \mathrm{ml})$ and of plasma gastrin in the guinea pig fundus in vitro. Clin. Endocrinol. 3: 389, 1974.

20. Maren, T. H. Carbonic anhydrase: Chemistry, physiology, and inhibition. Physiol. Rev. 47: 597, 1967.

21. Mariano, E. C., Beloni, A., and Landor, J. H. Some properties shared by amino acids and entero-oxyntin. Ann. Surg. 188: 181, 1978.

22. Newman, P. H., Reeder, D. D., Davidson, W. D., Schneider, E., Miller, J. H., and Thompson, J. C. Acid secretion following portacaval shunting. Arch. Surg. 99: 369, 1969.

23. Orloff, M. J., Abbott, A. G., and Rosen, H. Nature of the humoral agent responsible for portacaval shuntrelated gastric hypersecretion in man. Am. J. Surg. 120: $237,1970$.

24. Orloff, M. J., Hyde, P. V. B., Kester, L. D., Grullman, R. C., and Bell, R. H., Jr. The intestinal phase hormone. World J. Surg. 3: 523, 1979.

25. Orloff, M. J., Villar-Valdes, H., Abbott, A. G., Williams, R. J., and Rosen, H. Site of origin of the hormone responsible for gastric hypersecretion associated with portacaval shunt. Surgery 68: 202, 1970.

26. Pavlov, I. P. The Work of the Digestive Glands. London: Griffin, 1900. Pp. 10-18.

27. Sachs, G., and Berglindh, T. In Leonard R. Johnson (Ed.), Physiology of the Gastrointestinal Tract. New York: Raven Press, 1981. Pp. 567-602.

28. Shapiro, B., Pienta, K., Heldsinger, A., and Vinik, A. I. Somatostatin is an agonist and noncompetitive antagonist of gastrin in oxyntic cell function. Endocrinology 109: 1117, 1981 .

29. Sircus, W. The intestinal phase of gastric secretion. Quart. J. Exp. Physiol. 38: 91, 1953.

30. Vinik, A. I., Klaff, L. J., and Heldsinger, A. Comparison of potency of acid secretagogues in activation of carbonic anhydrase in guinea pig parietal cells. Clin. Res. 27: 636A, 1979.

31. Way, T. W., Carens, D. W., and Deveney, C. W. The intestinal phase of gastric secretion: A pharmacologic profile of entero-oxyntin. Surgery 77: 841, 1975.

32. White, A., Handler, P., and Smith, E. L. Principals of Biochemistry, 5th ed. New York: McGraw-Hill, 1973. 